\title{
РОЛЬ ФОРМУВАННЯ НАВИЧОК ПСИХОГІГІЄНИ І КОМПЕТЕНТІСНОГО ПІДХОДУ У ПІДГОТОВЦІ МЕДИЧНОГО ПРАЦІВНИКА
}

\author{
ДВНЗ «Тернопільський державний медичний університет \\ імені І.Я. Горбачевського МОЗ України»
}

\begin{abstract}
Мета: оцінити поширеність і запропонувати критерії раннього виявлення несприятливих змін психосізіологічного стану медичних сестер, які працюють у терапевтичних і хірургічних відділеннях; дослідити адаптивні можливості молодих практично здорових осіб із рисами особистості, які корелюють із формуванням синдрому емоційного вигорання, щоб підібрати адекватні заходи попередження і швидкого усунення ознак синдрому емоційного вигорання.

Матеріали і методи. Обстежено 40 медичних сестер травматологічного, хірургічного та терапевтичного профрілю зі стажем роботи понад 5 років і 25 практично здорових студентів медичного університету за допомогою психодіагностичних методик.

Результати. Встановлено, що медичні сестри з ознаками синдрому емоційного вигорання мають високий рівень нейротизму, що спонукало шукати серед обстежених студентського віку ранні ознаки схильності до дизадаптивних реакцій, які закладають підґрунтя для формування психосоматичних розладів у майбутньому.

Висновки. Функціональні особливості метеочутливих студентів можна використовувати для раннього виявлення у студентському середовищі осіб групи ризику щодо синдрому емоційного вигорання, з метою навчання їх навичкам психогігієни та психопрофрілактики.
\end{abstract}

КЛЮчОВІ СЛОВА: метеочутливість, психогігієна, психопрофрілактика.

Робота медичного працівника часто включає проблеми етичного вибору, необхідності швидко прийняти оптимальне рішення в інтересах хворого, що важливо враховувати уже на стадії підготовки медичних кадрів. За даними сучасних досліджень, медичні сестри у ситуації вирішення етичної дилеми схильні приймати рішення переважно на основі особистого фрахового досвіду і раніше сорормованих етичних компетенцій, що не залежать від національної приналежності, а визначаються швидше стадією психосоціального розвитку особистості. Етичні міркування, які не є частиною особистості, хоча і визнаються обстеженими як зразки належної поведінки, не спрацьовують, коли потрібно прийняти конкретне рішення в інтересах пацієнта [8]. Ситуації прийняття рішення часто стають джерелом дистресу і подальшого емоційного вигорання, що відбивається на ефективності роботи медсестер і якості наданого догляду [10].

У літературі наводяться риси особистості, які сприяють розвитку синдрому емоційного вигорання: «невротичність; спонтанна агресивність; депресивність; сором'язливість; емоційна лабільність» та охарактеризовані численні методи медикаментозного лікування і психотерапевтичної корекції явищ синдрому емоційного вигорання [6;7;9]. Але актуальним залишається виявлення ранніх змін психологічного статусу медичних працівників групи ризику для попередження і більш швидкого та ефективного усунення наслідків психоемоційного перевантаження. Дослідження даного (c) Н.М. Волкова, В.М. Городовіченко, 2015 питання допоможе застосувати індивідуальний підхід у фрормуванні професійних компетенцій майбутніх медичних працівників.

Мета дослідження: оцінити поширеність і запропонувати критерії раннього виявлення несприятливих змін психофрізіологічного стану медичних сестер, які працюють у терапевтичних і хірургічних відділеннях, щоб підібрати адекватні заходи попередження і швидкого усунення ознак синдрому емоційного вигорання; дослідити адаптивні можливості молодих практично здорових осіб із рисами особистості, які корелюють із фрормуванням синдрому емоційного вигорання, для виявлення можливості індивідуального підходу у підготовці майбутніх медпрацівників.

Матеріали і методи. Обстежено 40 медичних сестер травматологічного, хірургічного та терапевтичного профілю зі стажем роботи понад п'ять років у центральних міських лікарнях міст Тореза, Шахтарська, Сніжного. Дослідження проводилося протягом 120 днів у три етапи. На першому етапі дослідження були виявлені соціально-демографічні характеристики досліджуваних та характеристика емоційного стану медичних сестер, визначений рівень нейротизму за допомогою запитальника Г. Айзенка ЕРІ. Була проведена діагностика фрормування синдрому «емоційного вигорання» у медичних сестер за методикою В.В. Бойко. На другому етапі визначали рівень сорормованості емоційного вигорання та індивідуальні особливості професійного вигорання. 3 цією метою використовувався запитальник «Професійне (емоційне) вигорання», 
розроблений на підставі трифракторної моделі К. Маслач та С. Джексон і адаптований Н. Водоп яновою та О. Старченковою. На третьому етапі дослідження аналізували предметно-діяльнісний і комунікативний аспекти у структурі особистості за допомогою тесту темпераменту В.М. Русалова.

Вивчали психофрізіологічні особливості 25 практично здорових студентів медичного університету, які мали високий рівень нейротизму за запитальником Г. Айзенка ЕРІ. Для комплексної оцінки особистості використали Міннесотський багатофракторний особовий перелік (MМPI) авторів І. Маккінлі і С. Хатеуей у модифікації Л.Н. Собчик $(2000,2009)$. Оцінювали ефективність автономної регуляції серцевого ритму обстежених при виконанні когнітивних функцій за умов зниженого атмосфрерного тиску при III типі погоди, яка характеризується зниженим вмістом кисню у повітрі.

Результати дослідження та їх обговорення. Нами встановлено, що медичні сестри з високим рівнем нейротизму більш схильні до розвитку невротичних розладів внаслідок напружених умов праці. Найбільший рівень нейротизму був серед медичних сестер терапевтичного відділення. Медичні сестри травматологічного і хірургічного відділень виявили збереження організованої поведінки, ситуативної цілеспрямованості у звичайних і стресових ситуаціях. Серед складових емоційного вигорання найбільш несприятливими змінами емоційно-вольової сфери обстежених вважали досягнення фрази «виснаження», яка характеризується падінням емоційного тонусу й ослабленням нервової системи.

У медичних сестер виявлено комплекс психічних переживань і поведінки, що відбиваються на працездатності, фрізичному і психологічному самопочутті, а також на інтерперсональних відносинах працівника. За середніми показниками фаз розвитку стресу у медичних сестер терапевтичного та хірургічного профрілю фраза «резистенція» знаходиться в стадії розвитку. У медсестер терапевтичного відділення цей показник має найбільше значення та доходить до стадії сорормованості. Отримані результати пояснили тим, що у терапевтичному відділенні лікувалися тяжкохворі пацієнти, які потребували хоспісної допомоги.

Високий рівень професійного вигорання виявили у 50\% медсестер терапевтичного відділення, у 31\% медсестер хірургічного відділення та у 29\% медсестер травматологічного відділення. Серед найбільш несприятливих проявів професійного вигорання у медсестер терапевтичного відділення слід назвати деперсоналізацію й емоційне виснаження. У частини обстежених виявлено ознаки редукції особистих досягнень, що є показником зниження ефективності їх професійної діяльності.

Дезадаптивні зміни психоемоційного статусу у 34\% медичних сестер терапевтичного відділення проявляються симптомами емоційного дефіциту, емоційної відчуженості, особистісної відчуженості, емоційного дефіциту, тривоги і депресії, психосоматичних і психовегетативних порушень.

За даними кореляційного аналізу, існує обернена залежність між станом тривожного напруження, коли погіршується настрій, з'являється роздратованість, та емоційністю і пластичністю у спілкуванні. При спілкуванні з людьми з'являється захисна поведінка за типом «неучасті», бажання уникати емоційних реакцій вносить елементи поверхневості та фрормалізму. Така фрорма захисту може переноситись і за межі робочого кабінету, тобто стати нормою спілкування з друзями та в колі сім ї. Чим легше медичні сестри перемикаються з виконання одного виду діяльності на інший, тим менше відчувають редукцію профресійних обов'язків та емоційний десріцит.

Стаж роботи суттєво впливає на фрормування синдрому профресійного вигорання у медичних сестер. Виявлено високу достовірну пряму кореляцію між стажем роботи і симптомами тривоги та депресії ( $r=0,7 ; p \leq 0,01)$, середню пряму кореляцію тривоги, депресії та неадекватного емоційного реагування 3 редукцією професійних обов'язків $(r=0,6 ; p \leq 0,01)$. При цьому темп роботи суттєво не залежав від ознак емоційної напруги.

Таким чином, близько третини медичних сестер 3 високим рівнем нейротизму і стажем роботи понад п'ять років є групою ризику для розвитку високої інтенсивності синдрому емоційного вигорання.

Обстеження практично здорових студентів із високим нейротизмом виявило, що переважна більшість із них, навіть на суб'єктивному рівні, відчували помітне зниження працездатності, сонливість, головний біль, дратівливість при несприятливій дощовій погоді зі зниженим атмосферним тиском, яка відома як метеоситуація III типу. Отже, переважна більшість цих обстежених були метеочутливими. У цій групі обстежених при виконанні тестового розумового навантаження при несприятливій погоді виявлено меншу ефективність розумової праці. Психологічне тестування виявило акцентуації темпераменту за іпохондричними, депресивними, психопатичними, паранояльними, психоастенічними та шизоїдними рисами особи, які створюють передумови для низької працездатності, інтелектуальної продуктивності і соціальної відповідальності. Водночас результати тестування характеризували обстежених як особистостей 3 гнучким розумом, оригінальними судженнями, які відрізняються широтою інтересів і творчим характером мислення [1]. Аналіз автономного контролю серцевого ритму виявив у них надмірне напруження регуляторних систем із явищами десинхронозу. Такий тип реактивності закладає підґрунтя для формування психосоматичних розладів у майбутньому і може бути скоригований за допомогою за- 
гальновідомих заходів здорового способу життя, зокрема фрізичних тренувань [2;3].

Високу метеочутливість можна вважати ознакою схильності до дизадаптивних реакцій на стресове навантаження і використовувати для виявлення осіб групи ризику. На нашу думку, студентський вік найкраще підходить для створення основ профрілактики фрормування дизадаптивних реакцій, які 3 високою імовірністю можуть відбутися у наступній професійній діяльності. Доцільно навчати студентів навичок здорового способу життя, фрормувати в них емоційні компетенції і здатність до самонавчання, саморозвитку, щоб емоційно лабільна молода людина 3 гнучким розумом і творчими здібностями не перетворилася через 10-15 років на неврівноважену, байдужу, ще досить працездатну людину 3 неадекватними емоційними реакціями та автоматичним виконанням професійних дій.

Отже, професійні навички медичної сестри мають включати компетентність у питаннях здорового способу життя, медсестринської психотерапії, психогігієни і психопрофрілактики. Увага до власного здоров я повинна ставати частиною професійної культури медпрацівника і навіть, певною мірою, показником його професійної компетенції [4]. Ірраціональні когнітивні установки, неадекватне емоційне і поведінкове реагування, тенденція пригнічувати переживання в собі, витісняти емоційні реакції, пов'язані 3 роботою, відсутність звернень за психологічною допомогою, схильність нехтувати власним здоров'ям можуть свідчити про низьку компетентність та низьку профресійну культуру медичного фрахівця.

У літературі охарактеризовано деструктивний характерзмінособистостіприемоційномувигоранні [5] та показана можливість корекції психологічногостанупрацівниківза допомогоюпсихологічного тренінгу, який навчає емоційної саморегуляції [6]. Існує широке поле методів психокорекції і психопрофрілактики, які пропонується закордонними авторами [9], зокрема це методи психодрами, поведінкової, когнітивної терапії тощо. Отже, існує реальна можливість покращити психологічний стан медпрацівників і запобігти фрормуванню шкідливих наслідків синдрому емоційного вигорання.

\section{Висновки}

Медичні сестри 3 високим рівнем нейротизму більш схильні до розвитку невротичних розладів внаслідок напружених умов праці. Близько третини медичних сестер з високим рівнем нейротизму і стажем роботи понад п'ять років є групою ризику для розвитку високої інтенсивності синдрому емоційного вигорання.

Високу метеочутливість можна вважати ознакою схильності до дизадаптивних реакцій на стресове навантаження і використовувати для виявлення осіб групи ризику.

Студентський вік найкраще підходить для навчання заходів здорового способу життя, фрормування етичних компетенцій, що слугуватиме підґрунтям для профрілактики фрормування дизадаптивних реакцій, які з високою імовірністю можуть відбутися у наступній професійній діяльності.

Доцільно виявляти серед медпрацівників метеочутливих та дратівливих осіб і навчати їх навичок саморегуляції емоційного стану у типових профресійних ситуаціях, які потребують швидкого реагування і потенційно створюють високе навантаження на психоемоційну сореру.

Перспективи подальших досліджень. Доцільно порівняти ефективність препаратів адаптогенної дії, як можливих засобів покращання працездатності, зокрема для фрахівців медичної галузі.

\section{Список літератури}

1. Волкова Н. М. Психологічний статус практично здорових студентів з високою метеочутливістю / Н. М. Волкова // Журнал психіатрії та мед. психології. - 2008. - № 3 (20). - С. 36-42.

2. Волкова Н. М. Роль автономної регуляції у механізмах метеотропних реакцій практично здорових дорослих осіб / Н. М. Волкова // Довкілля та здоров'я. - 2009. - № 1 (48). - С. 18-21.

3. Волкова Н. М. Характеристика реакції на несприятливу метеоситуацію фрізично тренованих осіб у віковому аспекті / Н. М. Волкова // Вісник Вінницького нац. мед. ун-ту. - 2011. - Т. 15, № 2. - С. 221-224.

4. Европейская декларация по охране психического здоровья [Электронный ресурс] / Европейская консреренция ВОЗ на уровне министров по охране психического здоровья. Проблемы и пути их решения, Хельсинки, Финляндия, 12-15 января 2005 г. - Режим доступа : http://www.euro.who.int/_data/assets/pdf_ file/0011/88598/E85445R.pdf. - Назва з екрану.

5. Лаврова М. Г. Теоретичний аналіз сучасних поглядів на поняття «емоційне вигорання» [Електронний ресурс] / М. Г. Лаврова // Вісник Одеського нац. ун-ту. Психологія. - 2014. - Т. 19, Вип. 2. - С. 194-202. - Режим доступу : http://nbuv.gov.ua/j-pdf/Vonu_psi_2014_19_2_23.pdf. - Назва з екрану.

6. Щербан Т. Д. Основні напрямки психопросрілактики синдрому емоційного вигорання фрінансистів на різних етапах профресіоналізації / Т. Д. Щербан // Науковий вісн. Мукачівського держ. ун-ту. - 2014. - Вип. 2 (2). С. 162-168. - (Серія «Економіка»).

7. Hätinen M. Treating job burnout in employee rehabilitation / M. Hätinen. - Jyväskylä : University of Jyväskylä, 2008. $-85 \mathrm{p}$.

8. Nurses' responses to ethical dilemmas in nursing practice: meta-analysis / Dierckx De Casterle B., Izumi S., Godfrey N. S., Denhaerynck K. // Journal of Advanced Nursing. - 2008. - Vol. 63 (6). - P. 540-549; doi: 10.1111/j.13652648.2008.04702.x 
9. Oxford Guides in Cognitive Behavioural Therapy / A. Hackmann, J. Bennett-Levy, E. A. Holmes. - Oxford University Press, 2011. - $233 \mathrm{p}$.

10. Work Related Stress, Burnout, Job Satisfaction and General Health of Nurses / N. Khamisa, B. Oldenburg, K. Peltzer, D. Ilic // Int. J. Environ. Res. Public Health. - 2015. -Vol. 12. - P. 652-666; doi:10.3390/ijerph120100652

\section{РОЛЬ ФОРМИРОВАНИЯ НАВЫКОВ ПСИХОГИГИЕНЫ И КОМПЕТЕНТНОСТНОГО ПОДХОДА В ПОДГОТОВКЕ МЕДИЦИНСКОГО РАБОТНИКА}

Н.М. Волкова, В.М. Городовиченко

гВУУ «Тернопольский государственный медицинский университет им. И.Я. Горбачевского», Украина

Цель: оценить распространенность и предложить критерии раннего выявления неблагоприятных изменений психофизиологического состояния медицинских сестер, работающих в терапевтических и хирургических отделениях; исследовать адаптивные возможности молодых практически здоровых лиц с чертами личности, которые коррелируют с формированием синдрома эмоционального выгорания, чтобы подобрать адекватные меры предупреждения и быстрого устранения признаков синдрома эмоционального выгорания.

Материалы и методы. Обследовано 40 медицинских сестер травматологического, хирургического и терапевтического профиля со стажем работы более 5 лет и 25 практически здоровых студентов медицинского университета с помощью психодиагностических методик.

Результаты. Нами установлено, что медицинские сестры с признаками синдрома эмоционального выгорания имеют высокий уровень нейротизма, что побудило искать среди обследованных студенческого возраста ранние признаки склонности к дизадаптивным реакциям, которые закладывают основу для формирования психосоматических расстройств в будущем.

Выводы. Обнаруженные нами фуннциональные особенности метеочувствительных студентов можно использовать для раннего выявления в студенческой среде лиц группы риска касательно синдрома эмоционального выгорания с целью их обучения навыкам психогигиены и психопрофилактики.

КЛЮЧЕВЫЕ СЛОВА: метеочувствительность, психогигиена, психопрофилактика.

\section{ROLE OF BUILDING MENTAL HEALTH AND COMPETENCE APPROACH SKILLS IN TRAINING HEALTH CARE PROFESSIONALS}

N.M. Volkova, V.M. Horodovichenko

Ternopil State Medical University named by I.Ya. Horbachevsky, Ukraine

Purpose: to evaluate criteria for early detection of adverse changes of psychophysiological state of nurses, who work in therapeutic and surgical wards, explore adaptive capacity of young healthy individuals with personality traits, correlating with formation of emotional burnout syndrome to choose the adequate measures to prevent and for rapid elimination of emotional burnout syndrome.

Materials and methods. The study involved 40 nurses of trauma, surgical and therapeutic profile, with experience of over 5 years; 25 healthy medical students using psychodiagnostic methods.

Results. We found that nurses with emotional burnout syndrome have a high level of neuroticizm, prompting search among surveyed college-age early signs of predisposition to disadaptive reactions, causing formation of psycho-somatic disorders in the future.

Conclusions. We identified functional features of meteosensitive students, that can be used for early detection of persons at risk on emotional burnout syndrome, to their education in psychohygiene and psychoprophylaxis skills.

KEY WORDS: meteosensitivity, mental hygiene, psychological prophylaxis.

Рукопис надійшов до редакції 08.10.2015 p.

\section{Відомості про авторів}

Волкова Наталія Михайлівна - зав. кафредри медичної біоетики і деонтології дВНЗ «Тернопільський державний медичний університет ім. І.Я. Горбачевського МОЗ України»; тел.: 0961337517

Городовиченко Віра Михайлівна - Торезьке медичне училище; тел. служб.: +38(0352) 52-50-17 